\title{
Voiceless Victims of War: An Absurd Truth
}

\author{
Bhagyalaxmi Das and Itishri Sarangi \\ KIIT University, Odisha, India. Email: bhagyalaxmidas4o@gmail.com
}

Received January 2, 2017; Revised April 10, 2017; Accepted April 20, 2017; Published May 7, 2017.

\begin{abstract}
Literature written during and after World War II expresses an important ecological shift in human perception towards the concern for the environment. Prior to that writers and poets expressed the celebrated role of nature often expressed in Romanticism. A shift in focus was noticed in the absurdist texts written, between the 1940s and 1950s. The writers belonging to the absurd school of thought hinted at an ecological crisis that people were dimly aware of but a serious concern that was slowly paving ground. Ecology outlines the fundamental principle that everything and everyone in this universe is connected. Based on this principle, the paper offers an exposure of how a new concern for the ecology emerged in the absurdist text of the 1940s and 1950s, portraying the troubled relationship between the ecology and man. The paper also traces the atrocity on animals and nature during the two World Wars and how the strangeness of the universe affected the 'other than human' forms on planet earth.
\end{abstract}

Keywords: world war, absurd, ecology, nature, absurdist plays, war animals

\section{Introduction}

The most rambunctious wars in human history, the world war I and II claimed more than ninety million human lives and left the rest of the survivors with an indelible scar. Humanity voiced its helplessness and for the first time assumed that life was meaningless and every human action worthless. Literature is a reflection of its times and as such these feelings were reflected in the literary works of the French Philosopher, writer and journalist, Albert Camus. The absurd school of thought founded by him depicted life as meaningless and absurd. Absurdism as defined by Camus is a school of thought stating that life is meaningless and purposeless. Camus stated that instead of ending our lives because it is meaningless, one must cope with the absurdity and think of ways to enrich life. The irony lies in the fact that, absurdity does not encompass only humans. It impinges on all living creatures including plants and animals. The war had an appalling impact on nature and animals as well. Large number of forests and wildlife were destroyed completely due to the prolonged war. The central predicament of man: the absurd came to apply to nature as well. Dogs, horses, pigeons and even glowworms were active participants in the war. If absurdity encompassed 'meaninglessness', then they complied with the absurdity by engaging and sacrificing their lives in a war that made no sense to them. They died not only in the battlefields and from shellfire attacks but also from exposure to lethal gases, disease and hunger. The absurd universe remained indifferent to their sufferings. Like humans, they became victims of the absurdity and sufferings of existence. Anthropocentric views ignore the fact that nature is omnipresent and immortal. We must perceive the natural world as having a life and world of its own. Besides humans, animals, birds, insects, waterfalls and even stones and rivers have a language of their own. In some countries like India and Nepal, nature is regarded as a living force.

(c) AesthetixMS 2016. This Open Access article is published under a Creative Commons Attribution Non-Commercial 4.0 International License (http://creativecommons.org/licenses/by-nc/4.o/), which permits non-commercial re-use, distribution, and reproduction in any medium, provided the original work is properly cited. For citation use the DOI. For commercial re-use, please contact editor@rupkatha.com. 
People worship natural objects such as trees and stones as totems. With the advent of modernisation these values are eroding. Worship of nature has come to be regarded as a blind belief. As superior beings gifted with the ability to think, we must not deter from our responsibility towards caring and preserving nature and other non human life forms. Nature is a healer and the mother of mankind. If a cut hand is thrown on the soil, it decays, but even the smallest of a twig when planted, grows into a huge tree spreading fragrance and cleansing the air. The ravages of human war have always been healed by nature. Today we see green grass carpeting those areas once ravaged by war. American humanitarian worker, Corinna Haven Smith (18761965) while touring the former war zones noticed a tremendous change in the war affected areas. Gushing with surprise, Smith remarked: "Is this the same plain? It does not seem possible... Men are working in the fields... Grass has grown over the shell holes and sheep and goats are grazing among abandoned tanks... Only the trees have kept their record of suffering." The transformation she had witnessed led her to conclude that "Nature seems always to make an effort to cover the scars of battle as soon as possible." (Smith/Hill, 1920: 23) Of all the wars waged by mankind, World War II had bitter consequences on the ecosystem. Earth became the voiceless casualty of war. Particularly during the two wars, there was heavy use of modernised warfare. Nature bore the brunt of this mechanised and industrialized warfare. Educated soldiers well acquainted with the romantic appreciation of nature decried over the reality. Prolonged war caused near about extinction of some species of plants and animals, like the European bison. Many of them died from direct attacks and by the year 1918, starving troops had butchered the remaining of the animals. War also changed the landscape. During the war, men battling in the arid land of Mesopotamia craved for water more than food. But surprisingly, soldiers complained not for a lack of water, but an overabundance. This was due to the fact that rivers and lakes were snow fed during spring. As a result marshlands and shallow ponds dotted the alluvial plains. Inorder to preserve the water, combatants built trenches and protective dams. This changed the course of the rivers permanently. At the same time the mobilization of the army in the Alps intensified the process of industrialization on the peak with roads, railways and trails being built for them on an unprecedented scale. For their convenience, army engineers drilled mother earth to build army bases and establish electric stations and high-altitude observation posts. Degradation of the Alps took place in its most vicious form. The war also dealt a heavy blow to agriculture. War ravaged agricultural fields and destroyed a powerful means of livelihood. Fertile lands transformed to wastelands. Meanwhile pastoral lands were destroyed resulting in loss of food for cattle and other domestic animals. Consistent war brought such kind of drastic changes to the ecosystem. While ecosystems develop and change on their own, change due to human endeavour brings about drastic changes and nature vents it in unexpected ways.

\section{Voiceless victims of war}

The sacrifice of the nearly ninety million men in the two great wars has been reminisced since ages, but we are totally oblivient of the sacrifice, animals made to fight a battle that made no sense to them. Elephants, camels, dogs, carrier pigeons and even glowworms were deployed in huge numbers to fight an absurd war. They had no choice but to fight along with their human counterparts. The animals were the voiceless soldiers of war. British Author, Hugh Lofting believed that the animals might have vented their fear and suffering in a language only understood by them. Ironically, Hugh Lofting, a civil engineer, joined the regiment of the British Army and was commissioned as a lieutenant in the Irish Guards, to serve in the first world war. During his long stay in the trenches, he wrote imaginary letters to his children in order to keep 
them away from the brutalities of war. These letters later became the storyline of his popular novel series for children, Doctor Dolittle. His main character Doctor John Dolittle, an English physician could actually speak to animals and understand their language. Apparently Loftman had been a silent spectator to the cruelty imposed upon animals during the war. The death in thousands of regimental horses wounded in the battle affected him deeply. So he framed an imaginary character who could understand their language. Following Loftings felicitation for composing the Dolittle series in 1923, Irene Smith mentions in her book, History of the Newbery and Caldecott Medals that after receiving the second Newbery Medal he was asked by Mr. R. R. Bowker about how Doctor Dolittle had originated. Lofting said that at the front he had been so impressed by the bravery displayed by horses and mules that he invented the imaginary doctor to do justice to them which he otherwise was unable to do.

The use of animals in war was not being done for the first time as history shows animals such as elephants and horses used rampantly by emperors. Even monkeys were used to haul bombs by the Chinese. However, animal casualties reached its peak during the two great wars. During the entire span of the battle of Verdun nearly thirty two million shells were fired, out of which the British used about two hundred and fifty million shells. As rail, truck or ship could not suffice in transporting them, horses, mules, donkeys, oxen and even dogs were used for transportation. They were also used to carry gun, heavy artillery and loads of food. The dead and wounded were carted off in horse drawn ambulances and soldiers at the front were consistently sent supplies by animals. Even the British army, the most mechanised of the allied forces was largely dependant on animals especially horses. An estimated thirty four thousand tons of meat and fourty five thousand tons of bread were transported to the front on a monthly basis. Prolonged war eventually caused acute food shortages and the animals who transported the food ironically died of hunger themselves. Horses were the most widely used animals in the war. Nearly eight million died, not only in battle, but also from disease and hunger. They were so hungry that at the end they mistook their gas masks as food sacks and died out of choking. With most of the horses being deployed in the battlefield, the necessity arose in France mainly to transport goods and materials within the city. Elephants arose to the rescue. They started being used for transportation purposes. With so many horses deployed at work in France, an alternative had to be arranged to transport food and the heavy loads. In certain areas like Sheffield, circus elephants began to be used to carry ammunitions and machinery around the city. On the battlefront animals ran various errands and even proved worthy like the pigeons carried messages, oxen hauled guns, and even tiny glowworms endowed with the prowess to emit natural light were used in thousands. They were collected in jars and used by soldiers as lamps in the blacked-out trenches. While mentioning animals, the role of dogs would never go untrespassed. Nearly 20,00o dogs worked for the allies transporting small equipments on their backs and concealing messages in their collars. They also laid telephone lines and distributed first aid kits. They fought valiantly and saved lives despite not understanding why men fought. One such heroic dog, Satan, saved a beleaguered French battalion by delivering a message, despite being severely wounded by gunfire in the battle of Verdun. The most courageous war canine was Stubby, a U.S. combat dog, who saved many lives during the war. Stubby was trained in war by Commander J. Learning and was given expertise to identify the smell of mustard gas and gun his ears to the high-pitched whistling sound of shells. He often saved lives by barking or nipping at the toes of sleeping soldiers. When soldiers were trapped in no-man's-land, Stubby was sent to locate them. He was so alert in saving men that once he passed upon a soldier sleeping in a trench so soundly that he had not heard the topside alarm. Stubby stirred him awake, saving him serious injury from the shell attack. Finally Stubby was wounded by shrapnel in the Battle of 
Seicheprey, he was operated on and later returned to duty in one of the most dangerous war zones on the western front: the Marne. Stubby, the little dog was a war hero, admired by the women folk who expressed their gratitude by tailoring a coat of chamois leather for him. A Purple Heart, the Republic of France Grande War Medal, and the New Haven World War I Veterans Medal were some of the prestigious medals that hung from his coat that proudly displayed innumerable medals. Stubby died on April 4, 1926. Taxidermied, he stands mighty proud of his medals at the National Museum of American History in Washington.

The sacrifice made by animals goes incomplete without mentioning the contribution of the winged heroes. War had damaged most of the telephone lines and the modern means of communication that we have today were not yet invented. Pigeons are naturally endowed with tiny magnetic tissues in their brains that enable them to sense the earth's magnetic field and so pigeons have been successful in carrying messages to long distances. In such a case, pigeons were the only and most vital means of transmitting messages. Such was their importance that killing or wounding a carrier pigeon surmounted to six months imprisonment. A carrier pigeon named Cher Ami became a legendary hero of Verdun. Donated by the British to the U.S. Signal Corps, he served with the 77th Infantry Division. Cher Ami braved her life to save 194 American soldiers trapped behind German lines in 1918. She made it to the headquarters delivering the message: "For heaven's sake, stop it.", despite having been shot through the breast, blinded in one eye with a leg completely damaged. After the war, Cher Ami was honoured with France's highest military award, the Croix de Guerre, and today the taxidermied Ami stands mighty proud in the National Museum of American History. Out of the lot, thirty two others have been awarded worldwide for their services in saving human lives. In life, every truth is absurd and every absurd is truth. The truth is that while a tiny bird with the brain a size of a peanut could not make sense of an absurd human war, it risked its life to save the lives of humans.

Concern for the ecology and its sustenance grew increasingly during World War II. Men fighting at the front and behind the lines wrote expressive letters to their kin describing the war scenes through words such as, "fields of sterility", "the earth itself is corpse like", "devastated", "dreary", "savage", "hideously scarred" and more. Artists used palettes of greys, browns and black rather than the colourful hues of greens and blues. The historian George Mosse (1918-1999) wrote that the war led to a "heightened awareness of nature." (Mosse, 1991: 13). Nuclear attack on Hiroshima and Nagasaki in 1945 drew attention to the long term harmful impact of radiation in the atmosphere; industrialisation had already brought in emission of carbon monoxide and sulphur dioxide and people realised that inhaling these gases was like dying a slow death; the further development of consumer capitalism intensified the exploitation of the earth's natural resources for the development and progress of mankind. This growing concern was reflected in the absurdist texts of the period ranging from 1940's to 196o's. The absurd school of thought propounded people's belief that life is meaningless and the universe is silent and indifferent to our sufferings. Avant-garde writers belonging to these schools were 'men thinking for men'. They feared that ecological imbalance created by war would affect the earth and its future generations. Playwrights belonging to the theatre of the absurd showcased the theatre's troubled relationship with ecology and the environment. Ecocritics questioned; What role does the physical setting play in the novel? Are the values expressed in the play or novel consistent with ecological wisdom? How is nature, presented and interpreted in the literary works? Facing these questions and also expressing their concern, these writers hinted at the troubled relationship brewing between man and the environment. Through their works they hinted at the environmental hazards we are yet to face and how nature would take its vengeance on mankind already evident in the consequences of global warming and frequent earthquakes. 


\section{Greening the absurd in Albert Camus' works}

Albert Camus wrote and addressed his views during a time when the world was recuperating from the effects of war. His works portray the human being as a mortal suffering from maladies such as entropy, without any hope for redemption. Camus' views ran against the anthropocentric view that we are the only protagonists on this planet that are worthy of being the centre of attraction. Man's search for meaning meets with the coldness and strangeness of the universe. This strangeness of the universe offers a different ideology. It conveys the idea that no one really cares for our safety and wellbeing apart from we ourselves. So it is our sole duty to preserve, earth, our only home. In Camus' seminal essay on the absurd, he says; "In a universe suddenly divested of illusions and lights, man feels an alien, a stranger. His exile is without remedy since he is deprived of the memory of a lost home or the hope of a promised land. This divorce between man and his life, the actor and his setting, is properly the feeling of absurdity." (Camus, 1955: 5) By defining absurdity as the divorce between man and his settings, Camus hinted at the estrangement between man and his environment. Alighting into an alien world, man experiences a sense of exile and is determined to find a meaning.

Camus' association with the ecology can be traced to his childhood years. As a little boy he loved the Algerian soil, the beaches and the sun. He belonged to nature and nature belonged to him. This intense love and respect for nature shaped his philosophical views and formed a substantial part of his writings. Inundated by acute poverty on one side and the beauty of nature on another, he realised from an early age that life was an amalgamation of beauty and ugliness. The good and the evil would always coexist and he framed his fictional stories accordingly. Life ran deeply absurd for the man who coined the 'absurd theory'. Although he rose from the son of a cleaning woman to a Nobel laureate, he remained as pacified as the Algerian Mediterranean waves that inspired him. Nature made him a 'man' and so in all his novels, plays and essays, he gives undue importance to the sun and the sea as well as other elements of nature inorder to show their universal significance. Nature is an indispensable part of his work also because he witnessed the World War II from close quarters and expressed concern over the consequences it would inflict on the Earth. Secondly, he firmly believed that man and nature exist in a symbiotic relationship. Any harm to nature will result in ultimate doom for mankind.

Camus considered himself rich as he was blessed abundantly with the Algerian beaches and the beauty of sunburst bodies on the beaches. Later the sun plays a pivotal role in his seminal novel on the absurd, The Stranger (1942). The sun has a deep influence on the protagonist, Mersault and literally controls the narrative. The sun's mood elicits equivalent responses in Mersault, the absurd hero and shapes the story. Like Camus, Mersault enjoys the beaches and the sun, though he does not show any other humanly reactions. His reaction to the sun is the only evident human reaction. At the very beginning the sun's overbearing presence during the funeral procession causes Meursault far more pain than her death. The sun's tormenting rays on the beach compels him to kill the Arab. The fact that the sun controls Meursault's actions symbolises that the sun represents the absurdity inherent in the universe and in life. The sun is similar to the society. Both impose rules for forms of conduct and humans are expected to abide by the rules. Humans are expected to behave, react and act according to a set of rules imposed by society. For example, if you do not cry at your mother's funeral, you will be considered an outsider. A fact well established in The Stranger. Similarly, we wake up when the sun rises and retire when the sun sets. If we follow the reverse pattern, then we shall be considered vampires not humans. The absurdity of human life lies in the fact that a huge mass of energy and fire governs and controls 
our lives and sets a pattern for the entire universe. Without the sun, life on earth would perish. The sun is also a symbolic representation of Meursault's repressed emotions. As the novel portrays him as a man devoid of human emotions, but very much in love with the sun and the sea. Matters of the heart do not influence him as much as the wings of nature. The burning sun during his mother's funeral disturbs him more than his mother's death. He derives great sensual pleasure from Marie, his girlfriend and experiences sheer bliss from swimming with her in the Mediterranean waters, but is unable to reply when asked by Marie whether he would marry her or not. Later he kills an Arab on the beach not out of personal grievance, but because the sun blinds him in the eye and forces him to commit the crime out of irritation. He is tried and convicted not for the crime, but for adhering to societal norms. He finally realises that the world is indifferent to his sufferings and all these years the only happiness he has known is the sensory pleasures derived from the sun and the beach. The sun's role in the narrative can be divided into three phases: Mersualt's time spent with Marie on the beach, the murder and the memories of the sea in prison. The time spent with Marie reveals his harmony with life and nature. On the day of the murder, he turns to the sea for solace, but the sun blindfolds him and forces him to commit the crime. In prison, the only good memories he has is that of the pleasure derived from the sea. At the time of his execution, the sea haunts his memory, but this time with its odour and arduous tides. Very rarely does Camus show us negative aspects of nature. Here he does so to hint at the possible consequences of man's estrangement from nature. Camus brings out the fact that man is married to nature and as such any kind of divorce will result in his alienation. Rocks, mountains, cliffs, sea breeze and even flowers are not missed out in Camus' fictional works. Flowers also appear to be an indispensable part of his seascapes. In the essay, Nuptials at Tipasa he mentions a myriad of coloured flowers. Flowers are also an important part of the morning decor on the day of the murder in The Stranger. The use of flowers in the narrative help to establish an environment friendly atmosphere and also set a happy tone. Animal life is also not missed out. Lizards are seen on the hillsides above the sea at Tipasa. In La Mer au plus près, a flock of stags swim across the ship path and as they move northward a host of colourful birds follow suit and rest in their antlers. Camus often describes the birds that are found on or near the sea shores. Marine life replete with tortoises and flying fishes add full richness to La Mer au plus près.

While describing the sea, Camus describes it from the eyes of a Mediterranean pagan. One who shares the Greek awareness of tragedy combined with beauty. He also presents the sea in its myriad moods and whims. Later, when he moved to France, the absence of the Algerian Mediterranean sea made him realise how much he was at home, only near it. He wrote: "I grew up with the sea, and poverty for me was sumptuous; then I lost the sea and found all luxuries grey and poverty unbearable". (Hawes, 2010: 146)

Camus, inspired by the Greek philosophers lived a life of the senses. The sea exuberated warmth, colour, richness, beauty and joy and served as an antidote to death. Never did he imagine the sea as a lone entity. He presented the seascape as surrounded by mountains, the sky, flowers, aquatic life, animals and plants as well. He painted the sea in its myriad moods. This love for the sea is reflected in various ways: as an integral part of the story, as a means of seeking solace, as a form to be compared with material objects and as a symbol influencing his main character. His second collection of essays, Nuptials (Noces 1939) speaks volumes of the confluence between human experience and the natural world. Four essays, Nuptials at Tipasa, The Wind at Djemila, Summer in Algiers and The Desert are tributes to nature. Nuptials at Tipasa is a vivid description of Camus' relationship and dependency upon nature. In this essay, Camus celebrates his marriage with mother earth. He is all praise for the bonding between man and nature, but like a true humanist reveals his fear of living under the shadow of death without hope. He also expresses his 
intention of unifying with nature in a profound way. He wrote: "Yet people have often told me: there is nothing to be proud of. Yes, there is: this sun, this sea, my heart leaping with youth, the salt taste of my body and this vast landscape in which tenderness and glory merge in blue and yellow. It is to conquer this that I need my strength and my resources. Everything here leaves me intact, I surrender nothing of myself, and don no mask: learning patiently and ardently how to live is enough for me, well worth all their arts of living." (Camus, 1968: 69)

The last essay talks of the glory of sensual beauty. Nuptials sings the glory of the human body and its union with the earth and the sea. Germaine Bree said of the creation of these essays, published in 1938, that "he found himself strongly tempted to yield, to throw himself into a rapturous enjoyment of the beauty of the earth, and it is this temptation that is related in the four essays of Noces." (Bree, 1964: 79)

\section{Concern for the ecology in Samuel Beckett's Waiting for Godot}

Martin Esslin used the word absurd to frame the title of his famous book The Theatre of the Absurd (1960). Esslin used this word in a very literary sense to describe the writings of some post world war II playwrights who wrote plays of an unconventional and experimental type. Plays belonging to the Theatre of the absurd are a threatrical expression of the 'absurdity of the human condition'. Absurdism, in literature and drama, is usually presented in this way: humans searching for meaning in a world where meaning is either always elusive or nonexistent. Playwrights belonging to this school have profoundly expressed a sense of anxiety over the ecological and environmental issues that have become catastrophic over the ages. Samuel Beckett, its chief proponent wrote extensively in the wake of the World War II. Originally written in French, Waiting for Godot has been widely accepted as the greatest work of Beckett. It is regarded as the most significant English language play of the 2oth century. Two men, Vladimir and Estragon wait endlessly on a country road for someone named Godot. There is nothing in sight except a leafless tree. There is no action in the play except the only action being 'time'. Two men join them later. Pozzo the master Lucky the slave. After a long wait, a boy enters and informs Vladimir that Godot will come tomorrow. They decide to go move but stay on as the curtain falls. Act II opens in the same way and the two men meet again and wait for Godot. Pozzo and Lucky join again, but this time, Pozzo has been blinded and Lucky mute. The boy enters again, only to inform them that Godot will not be coming. They decide to move but remain static as the curtain falls.

Morality is a key concept in the play. Following the pain inflicted in life, morality is passed down from religion and God but can morality exist without god? In the war days, people began to question the existence of God. They asked, does God exist? If He does, why doesn't He come to our rescue. Beckett is himself an agnostic. In the play, Waiting for Godot, Beckett presents his audience an unspoken sense of dread and fear in a land derived of its dignity. The play opens in its first act with a barren tree placed at the centre of the stage. Two tramps enter looking for someone named Godot. Besides the two primary characters, Vladimir and Estragon, the tree forms a primary character in the play. Throughout it stands at the centre of the stage catching the attention of the audience. Vladimir and Estragon talk for long hours about the tree and even contemplate suicide by hanging from its branches. The tree which stands "all black and bare" in the first act sprouts a few leaves in the second act which astonishes the two protagonists who wonder whether it is possible for a tree to sprout leaves overnight. It is believed that the tree represents life and death in a cyclical fashion. There have been several interpretations of the 
significance of the tree in the play. From the ecological point of view, the tree signifies man's growing estrangement from nature. A naked tree reveals the atrocities imposed on nature due to war. Nature is our mother and protector, but we in turn like disobedient children have ravaged and disrespected her. In the ancient days, objects of nature, such as the sun and trees were objects of worship. Today man has lost this respect. If rape is about the overpowering and domination of another entity than man has raped nature of its self dignity. Beckett much aware and concerned about the ecological crisis of the late zoth century displays man's profound alienation from nature by staging a lifeless and naked tree. In Act II, a few leaves sprout signifying 'revival of hope' for mankind. The tree is the only character that shows some kind of progress and transformation. Beckett here tries to give his audience the message that between man and nature, nature is superior as it has the power to regenerate itself. Nature shows hope amidst despair and absurdity. Beckett's deep philosophical thinking forecasted that despite being hurt and humiliated at the hands of man, nature has forgiven and returned to normalcy. The tree in Waiting for Godot became symbolic of the Tree of Life in W. B. Yeats famous poem, The Two Trees. Here Yeats used the image of a tree in full bloom, laden with flowers and fruit to symbolise life and fertility and he contrasts it with a barren tree, which represents the state of humanity's isolation from God after the fall.

\section{Conclusion}

The war and the events that shook the world such as the nuclear attack on Hiroshima and Nakasaki, the Holocaust threw the very existence of life on this blue planet into a complex question. People realised collectively that life on the earth could no longer be taken for granted. Literature is a reflection of its times and so the writers of this period expressed their concern for the new environmental threat confronting mankind. The works belonging to the absurd school of thought and the theatre of the absurd are an archive of the ecological experience during the most turbulent times in human history. Beckett's use of barren lands and bizarre landscapes are a revelation towards an understanding of what it meant to live under the threat of nuclear annihilation. Deep ecological meanings are embedded within various forms of linguistic and emotional alienation that the absurd plays are so concerned to evoke and bring to the forefront.

Ecology teaches us that all living beings are connected. All thoughts emanating from our concern for the ecology are ecological thoughts. This ecological thought mitigates interconnectedness in the universe and raises awareness of how human beings are connected with other living beings. This ecological thought pervades the works of Albert Camus and Samuel Beckett. Human actions permeate the world of nature and animals and affects them just the way it affects the human world. While humans continue to destroy and control nature, not realising that they are not the only living creatures existing here. Absurd text and drama closely analyse how nature is at stake. Because of the interconnectedness of all living organisms, animals bore the brunt of a human war as much as the humans did. Beckett's drama casts the actors as lonely and alienated individuals cast away on an environmental background that is seen as threatened. The divorce between man and his surrounding is all represented in Beckett's plays.

The kind of ecological degradation pertaining to war came to be associated with the second-wave ecocriticism that is more directed towards sites of environmental devastation (including cities) and texts that do the same. Second-wave ecocriticism covers mostly the disappearance of cities, empires or civilisations and of the ravages caused by war, scientific warfare and industrialisation. He expressed his concern, saying, "It is perhaps the outer limit of 
revolt to lose one's faith in humanity. Perhaps after this war, trees will flower again, since the world always finally wins out over history, but on that day, I don't know how many men will be there to see it." (Todd, 2015: 93).

The war ended and nature regenerated itself. Years later, today we are enslaved by the forces of nature. Natural calamities like the tsunami, frequent earthquakes, massive depletion of natural resources such as petrol, destruction of entire ecosystems and mass species extinction are just a few examples of nature's vengeance on mankind. All it wants, is to teach man a few existential truths like compassion, selflessness and solidarity. We must realise that we are not alone on this planet. Since the two great wars, concern for the ecology or ecological consciousness has grown. Its essence has changed significantly. When the first cannons were fired in the early fourteenth century, people panicked about how it would affect the ecology. They exerted a pressure by sending workers frantically to the hills for more potash, sulphur, iron ore, and charcoal. It also resulted in soil erosion and deforestation. But the impact of hydrogen bombs was altogether different. Besides the combustion of fossil fuels, population explosion, urbanisation, large deposits of sewage and garbage have posed serious threat to the ecology. A bad child is one who dirties and spoils his own home. Just like a bad child, we have destroyed our own home. No creature other than man has managed to turn his home into garbage within such a short span. The day will probably come when we will be left homeless. We must accept with modesty that we are not the only species on this revolving planet blessed with fundamental life running elements like water and air. We are not the rulers of the planet and the world belongs as much to them as much as it belongs to us. As superior beings endowed with speaking and thinking abilities, it is our duty to look down upon others living beings with brotherhood and solidarity.

We have created and destroyed many civilizations never taking any opinion or facing opposition from the voiceless victims who are affected cavernously by the consequences of our actions. We are the only living species that have destroyed our own home. We are also the only one's who can restore normalcy and save our home from further ruin. Endowed with superior qualities, we have reached the depth of the ocean, changed the course of rivers, moved mountains, explored the galaxy and reached the moon. Considering our achievements, saving the earth is only but child's play. Nature cannot raise its voice against the anthropocentric human breed and ironically the only voice it can raise, is through us.

But in the end, we must realise that it is only us, who can give voice to these voiceless victims.

\author{
References \\ Ashworth, T. (2000). Trench Warfare, 1914-1918: the live and let live system. Pan Macmillan. \\ Bennett, M. (2011). Reassessing the theatre of the absurd: Camus, Beckett, Ionesco, Genet, and Pinter. \\ Springer. \\ Brée, G. (Ed.). (1964). Camus. Rutgers University Press. \\ Camus, A. (2012). Lyrical and critical essays. Vintage. \\ Camus, Albert, and Justin O'Brien. The Myth of Sisyphus, and other essays. Vintage, 1955. \\ Carson, Rachel. Silent spring. Houghton Mifflin Harcourt, 2002. \\ Closmann, C. E. (2009). War and the environment: military destruction in the modern age (Vol. 125). Texas \\ A\&M University Press.
}


Clout, H. D. (1996). After the ruins: restoring the countryside of northern France after the Great War. University of Exeter Press.

Collins, Sean P. "From Existentialism to Ecology: A Philosophical Analysis of Crisis in Samuel Beckett." (2016).

Coupe, Laurence. The green studies reader: from Romanticism to ecocriticism. Psychology Press, 2000.

Dobson, Andrew. "The green reader: Essays toward a sustainable society." (1991).

Dower, John W. War Without Mercy: Race E Power in the Pacific War. Pantheon Books, 1993.

Favreau, Marc. A People's History of World War II: The World's Most Destructive Conflict, as Told by the People who Lived Through it. The New Press, 2011.

Gavins, Joanna. Reading the absurd. Edinburgh University Press, 2013.

Glotfelty, C., \& Fromm, H. (Eds.). (1996). The ecocriticism reader: landmarks in literary ecology. University of Georgia Press.

Gontarski, Stanley E. "The Body in the Body of Beckett's Theater." Samuel Beckett Today/Aujourd'hui 11.1 (2002): 169-177.

Graver, Lawrence, and Raymond Federman. Samuel Beckett: the critical heritage. Psychology Press, 1997.

Haag, Edith, Joanne. (1966). The role of the sea in the fictional works of Albert Camus. Doctoral Dissertation, University Of Southern California, California.

Hawes, E. (2010). Camus, A romance. Grove/Atlantic, Inc..

Hynes, Samuel. A war imagined: the First World War and English culture. Random House, 2011.

Lewis, Charles A. "Green nature." (1996).

Morton, Timothy. "Hyperobjects: Philosophy and Ecology after the End of the World." (2013).

Morton, Timothy. Ecology without nature: Rethinking environmental aesthetics. Harvard University Press, 2007.

Morton, Timothy. The ecological thought. Harvard University Press, 2010.

Mosse, G. L. (1991). Fallen soldiers: Reshaping the memory of the world wars. Oxford University Press.

Smith, M. C. H. P., Smith, C. L., \& Hill, C. R. (1920). Rising Above the Ruins in France: An Account of the Progress Made Since the Armistice in the Devastated Regions in Reestablishing Industrial Activities and the Normal Life of the People. GP Putnam's sons.

Todd, O. (2015). Albert Camus: A Life. Random House.

Wetherill, Doster, Frank. (1964). Albert Camus and the Kingdom Of Nature. Doctoral Dissertation, University Of Southern California, California.

Worrall, S. (2015, April 29). How Little Seeds Shaped Human History in Big Ways. Retrieved April 25, 2016, from http://news.nationalgeographic.com/2015/04/150429-ngbooktalk-seeds-agriculture-food-scienceworld-book/

Worrall, S. (2016, July 28). On the Hundredth Anniversary of the Start of World War I, Remembering the Part Animals Played. Retrieved November 25, 2016, from

http://news.nationalgeographic.com/news/2014/o7/140728-world-war-horse-pigeons-dogs-glowwormsverdun-dickin-medal/

Bhagyalaxmi is a PhD Scholar in English Literature from School of Humanities, KIIT University, India. Currently working under the guidance of Dr. Itishri Sarangi, Assistant Professor II, School of Humanities, KIIT University. She is also a poet, author and critic. A firm believer in the philosophy of the absurd, Bhagyalaxmi dreams of carrying forward the Camusian dream of living in a world of harmony and brotherhood. 